\title{
Laparoscopic mesh repair of strangulated groin hernias requiring bowel resection
}

\author{
Alexander Smith, Jordan Bilezikian, William Hope, Sarah Fox \\ Department of General Surgery, Division of Gastrointestinal Surgery, Novant New Hanover Regional Medical Center, \\ Wilmington, NC 28401, USA. \\ Correspondence to: Dr. Sarah Fox, Department of Surgery, Division of Gastrointestinal Surgery, Novant New Hanover Regional \\ Medical Center, 2131 South 17th Street, PO Box 9025, Wilmington, NC 28401, USA. E-mail: sarah.fox@nhrmc.org \\ How to cite this article: Smith A, Bilezikian J, Hope W, Fox S. Laparoscopic mesh repair of strangulated groin hernias requiring \\ bowel resection. Mini-invasive Surg 2021;5:34. https://dx.doi.org/10.20517/2574-1225.2021.44
}

Received: 29 Mar 2021 First Decision: 13 Apr 2021 Revised: 26 Apr 2021 Accepted: 6 May 2021 First online: 1 Jul 2021

Academic Editor: Giulio Belli Copy Editor: Xi-Jun Chen Production Editor: Xi-Jun Chen

\begin{abstract}
No robust data support laparoscopic mesh repair in strangulated groin hernias. This is a retrospective review over 6 years of a single surgeon's experience treating strangulated groin hernias using the laparoscopic trans-abdominal preperitoneal mesh repair with concomitant bowel resection through a periumbilical incision. Nine patients presented with incarceration of 2 inguinal and 7 femoral hernias. The median age was 83 years (IQR 68, 85). One patient was male, all were Caucasian, and 5 were ASA 3-4. The median hospital length of stay was 6 days (IQR 4, 7). There were no known hernia recurrences or mesh infections at 30 days. Laparoscopic repair necessitates mesh placement, and doing so in a clean-contaminated setting is acceptably low risk. Laparoscopy permits better assessment of bowel viability compared to open repair and enables mesh coverage of both the inguinal and femoral spaces.
\end{abstract}

Keywords: Clean-contaminated mesh, strangulated hernias, trans-abdominal preperitoneal

\section{INTRODUCTION}

Strangulated groin hernia is a relatively rare condition that requires emergency surgical treatment. Groin hernia repair, however, is extremely common. Various techniques exist via open and minimally invasive approaches. The literature shows that laparoscopic repair for elective hernias has many benefits over the open approach. Similar complication and recurrence rates are seen, but there typically is less pain and time

The Author(s) 2021. Open Access This article is licensed under a Creative Commons Attribution 4.0 International License (https://creativecommons.org/licenses/by/4.0/), which permits unrestricted use, sharing, adaptation, distribution and reproduction in any medium or format, for any purpose, even commercially, as long as you give appropriate credit to the original author(s) and the source, provide a link to the Creative Commons license, and indicate if changes were made. 
needed for recovery ${ }^{[1,2]}$. Strangulated groin hernias present a more unique problem in which the contents of the hernia may be compromised and nonviable. Because of this, repair of these hernias was traditionally done via an open approach, partly due to the difficulty in safely reducing herniated contents laparoscopically. The other reason relates to the risk of leaving prosthetic material in a potentially infected field, therefore increasing surgical site infection risk and warranting open tissue repair ${ }^{[3]}$. Despite this dogma, laparoscopic repair with mesh has been documented as a safe approach for strangulated groin hernias $s^{[-8]}$. However, there are no robust data to support this. We present our experience with the use of laparoscopic repair of strangulated groin hernias with concomitant bowel resection to support that this is a safe and effective option.

\section{CASE REPORT Methods}

This is a retrospective review of a single surgeon's operative experience from January 2013 to July 2019 of all patients presenting with strangulated inguinal or femoral hernia who underwent laparoscopic transabdominal preperitoneal repair with small bowel resection. Demographic, perioperative, and shortterm outcomes were reviewed, and descriptive statistics were performed (Microsoft Excel, 2019).

\section{Results}

Nine patients underwent laparoscopic mesh repair and small bowel resection for strangulated inguinal or femoral hernia over 6 years. All patients initially presented to the emergency department (ED). Hernias were repaired laparoscopically with a trans-abdominal preperitoneal (TAPP) approach with Bard 3DMax ${ }^{\mathrm{TM}}$ light mesh and secured with Covidien $5 \mathrm{~mm}$ Protack $^{\mathrm{TM}}$, which is our preferred approach. Four tacks were used to secure the mesh in 8 cases, and one required 6 tacks. All patients had an open small bowel resection through a small periumbilical incision at the laparoscopic port site.

Diagnosis was made clinically in one patient and the remainder underwent computed tomography in the emergency department prior to evaluation by a surgeon. One patient with end-stage dementia was initially elected for hospice care and after $48 \mathrm{~h}$, the family decided to pursue surgery. Three patients had attempted hernia reduction in the ED, and one was successfully reduced, but reincarcerated and was repaired $6 \mathrm{~h}$ after presentation. The remainder were taken to the operating room within $4 \mathrm{~h}$ of presentation. Two hernias were direct inguinal and seven were femoral. One of the femoral hernias was recurrent, and one patient had bilateral femoral hernias, only one of which was incarcerated; both were repaired [Table 1]. In two cases, the surgeon was consulted intraoperatively by other surgeons that were on call.

The median age was 83 years (IQR 68, 85). One was male and all were Caucasian. Interestingly, none were diabetic. The median BMI was $20.97 \mathrm{~kg} / \mathrm{m}^{2}$ (IQR 19.93, 22.08). Five patients were ASA 3-4. Postoperative median hospital length of stay was 6 days (IQR 4, 7). Three patients were discharged to a skilled nursing facility, while the rest were discharged home. One patient developed a small deep pelvic abscess treated with CT-guided aspiration and antibiotics. Two patients were lost to follow up. There were no known hernia recurrences or mesh infections at 30 days, nor were any identified during the time of chart review. Four patients were deceased at time of chart review, and the one who died within 90 days postoperatively was the same patient that initially chose hospice [Tables 1 and 2].

\section{DISCUSSION}

Hernias of the groin are common, but strangulated groin hernias are relatively rare. The risk of strangulation is higher in the case of femoral hernias. The risk of strangulation in inguinal hernias is documented as $2.8 \%$ at 3 months, increasing to $4.5 \%$ at 2 years. Femoral hernias, on the other hand, carry a 
Table 1. Hospital course of patients presenting with strangulated groin hernias repaired by trans-abdominal preperitoneal mesh repair with concomitant small bowel resection

\begin{tabular}{|c|c|c|c|c|c|c|c|c|c|}
\hline $\mathbf{P t}$ & $\begin{array}{l}\text { Reduced in } \\
\text { ED }\end{array}$ & Hernia type & Diagnosis & Hospital course & $\begin{array}{l}\text { LOS, } \\
\text { days }\end{array}$ & $\begin{array}{l}\text { Discharge } \\
\text { location }\end{array}$ & $\begin{array}{l}\text { 30-day } \\
\text { outcomes }\end{array}$ & $\mathbf{F} / \mathbf{u}$ & Antibiotics \\
\hline A & $\begin{array}{l}\text { Not } \\
\text { attempted }\end{array}$ & $\begin{array}{l}\text { Strangulated right } \\
\text { femoral }\end{array}$ & $\mathrm{CT}$ & Ileus, TPN & 7 & Home & $\begin{array}{l}\text { No recurrence, } \\
\text { infection or } \\
\text { readmission }\end{array}$ & Yes & Preop \\
\hline B & $\begin{array}{l}\text { Attempted, } \\
\text { not reduced }\end{array}$ & $\begin{array}{l}\text { Strangulated left } \\
\text { direct inguinal }\end{array}$ & Clinical & $\begin{array}{l}\text { lleus, TPN, urinary retention, } \\
\text { pelvic abscess treated with } \\
\text { aspiration \& trimethoprim- } \\
\text { sulfamethoxazole }\end{array}$ & 12 & Home & $\begin{array}{l}\text { No recurrence, } \\
\text { infection or } \\
\text { readmission }\end{array}$ & Yes & $\begin{array}{l}5 \text { days } \\
\text { postop }\end{array}$ \\
\hline C & $\begin{array}{l}\text { Attempted, } \\
\text { not reduced }\end{array}$ & $\begin{array}{l}\text { Strangulated left } \\
\text { femoral }\end{array}$ & CT & Uneventful recovery & 5 & SNF & $\begin{array}{l}\text { No recurrence, } \\
\text { infection or } \\
\text { readmission }\end{array}$ & Yes & Preop \\
\hline D & $\begin{array}{l}\text { Attempted, } \\
\text { not reduced }\end{array}$ & $\begin{array}{l}\text { Strangulated left } \\
\text { femoral }\end{array}$ & CT & $\begin{array}{l}\text { Fall from bed, right face } \\
\text { hematoma }\end{array}$ & 4 & $\begin{array}{l}\text { Home with } \\
\text { home health }\end{array}$ & $\begin{array}{l}\text { No recurrence, } \\
\text { infection or } \\
\text { readmission }\end{array}$ & Yes & Preop \\
\hline E & $\begin{array}{l}\text { Not } \\
\text { attempted }\end{array}$ & $\begin{array}{l}\text { Strangulated left } \\
\text { femoral }\end{array}$ & CT & $\begin{array}{l}\text { Clostridium difficile diarrhea, } \\
\text { treated with metronidazole }\end{array}$ & 17 & SNF & $\begin{array}{l}\text { Readmitted within } \\
30 \text { days for MRSA } \\
\text { cellulitis on upper } \\
\text { extremity }\end{array}$ & No & 24 h postop \\
\hline $\mathrm{F}$ & $\begin{array}{l}\text { Not } \\
\text { attempted }\end{array}$ & $\begin{array}{l}\text { Strangulated right } \\
\text { femoral }\end{array}$ & CT & $\begin{array}{l}\text { Oral thrush, lleus, pulmonary } \\
\text { edema, HAP, urinary } \\
\text { retention }\end{array}$ & 7 & SNF & $\begin{array}{l}\text { No recurrence, } \\
\text { infection or } \\
\text { readmission }\end{array}$ & No & 24 h postop \\
\hline G & $\begin{array}{l}\text { Not } \\
\text { attempted }\end{array}$ & $\begin{array}{l}\text { Strangulated right } \\
\text { direct inguinal }\end{array}$ & Clinical, CT & lleus & 6 & Home & $\begin{array}{l}\text { No recurrence, } \\
\text { infection or } \\
\text { readmission }\end{array}$ & Yes & Preop \\
\hline $\mathrm{H}$ & $\begin{array}{l}\text { Not } \\
\text { attempted }\end{array}$ & $\begin{array}{l}\text { Strangulated } \\
\text { recurrent left } \\
\text { femoral }\end{array}$ & $\mathrm{CT}$ & Uneventful recovery & 2 & Home & $\begin{array}{l}\text { No recurrence, } \\
\text { infection or } \\
\text { readmission }\end{array}$ & Yes & Preop \\
\hline I & $\begin{array}{l}\text { Not } \\
\text { attempted }\end{array}$ & $\begin{array}{l}\text { Strangulated right } \\
\text { femoral, non- } \\
\text { incarcerated left } \\
\text { femoral }\end{array}$ & $\mathrm{CT}$ & Uneventful recovery & 4 & Home & $\begin{array}{l}\text { No recurrence, } \\
\text { infection or } \\
\text { readmission }\end{array}$ & Yes & Preop \\
\hline
\end{tabular}

Pt: Patient; ED: emergency department; LOS: length of stay; F/u: follow up; CT: computed tomography; TPN: total parenteral nutrition; HAP: hospital acquired pneumonia; SNF: skilled nursing facility; MRSA: methicillin resistant Staphylococcus aureus.

3-month strangulation risk of $22 \%$ and 21 -month risk of $45 \%{ }^{[9]}$. Laparoscopic and open approaches exist for repair of strangulated hernias. Although laparoscopic repair necessitates placement of mesh, doing so in a clean or clean-contaminated setting is considered acceptable. Furthermore, laparoscopy provides the ability to better assess bowel viability as compared to an open anterior repair ${ }^{[10]}$, and it permits mesh coverage of both the inguinal and femoral spaces. This study adds to the literature on the safety of the laparoscopic approach.

There is no clear consensus on the best surgical approach for repairing strangulated groin hernias, but many reports have demonstrated laparoscopic repair as a safe option. Matsuda et al. ${ }^{[4]}$ performed a retrospective review of patients with acute strangulated hernia who either underwent open anterior repair or laparoscopic TAPP repair. There were no recurrences in either group, and complication rates were similar. While TAPP took longer to perform, the associated hospital stay was shorter ${ }^{[4]}$. Chihara et al. ${ }^{[5]}$ prospectively followed patients with incarcerated or strangulated groin or obturator hernias who underwent either laparoscopic or open repair. In the laparoscopic group, one patient had conversion to a laparotomy, and 7 patients had a second-stage TAPP repair performed after bowel repair or resection. There were no instances of mesh infection in the laparoscopic group, but one patient did suffer mesh infection in the open group. While the laparoscopic method again took significantly longer, it also displayed a decreased postoperative complication rate and hospital length of stay ${ }^{[5]}$. 
Table 2. Patient demographics and comorbidities of patients presenting with strangulated groin hernias repaired by trans-abdominal preperitoneal mesh repair with concomitant small bowel resection

\begin{tabular}{|c|c|c|c|c|c|c|c|c|c|c|}
\hline $\mathbf{P t}$ & $\begin{array}{l}\text { Age, } \\
\text { years }\end{array}$ & Sex & ASA & Smoker & BMI & $\begin{array}{l}\text { Cardiac } \\
\text { history }\end{array}$ & $\begin{array}{l}\text { Pulmonary } \\
\text { history }\end{array}$ & $\begin{array}{l}\text { Other } \\
\text { history }\end{array}$ & Deceased & Cause of death \\
\hline A & 57 & $\mathrm{~F}$ & 2 & Current & 20.80 & HTN & COPD & & No & \\
\hline B & 68 & $\mathrm{~F}$ & 2 & Never & 20.97 & & & & No & \\
\hline C & 83 & $\mathrm{~F}$ & 3 & Former & 22.08 & HTN & & CVA & Yes & $\begin{array}{l}\text { Died in hospice from upper } \\
\text { gastrointestinal hemorrhage } 5 \text { years } \\
\text { later }\end{array}$ \\
\hline $\mathrm{D}$ & 93 & $\mathrm{~F}$ & 3 & Never & 22.03 & $\begin{array}{l}\text { HTN, CAD, } \\
\text { pacemaker, } \\
\text { CABG }\end{array}$ & & & Yes & $\begin{array}{l}\text { Died } 2 \text { years postoperatively, cause } \\
\text { not listed }\end{array}$ \\
\hline$E$ & 92 & M & 4 & Unknown & 18.64 & $\begin{array}{l}\text { HTN, CAD, } \\
\text { pacemaker, IHD }\end{array}$ & $\begin{array}{l}\text { COPD, } \\
\text { pulmonary } \\
\text { HTN }\end{array}$ & Dementia & Yes & $\begin{array}{l}\text { Readmitted } 6 \text { weeks postoperatively } \\
\text { and died from CHF exacerbation and } \\
\text { MRSA cellulitis }\end{array}$ \\
\hline $\mathrm{F}$ & 85 & $\mathrm{~F}$ & 4 & Current & 19.93 & $\begin{array}{l}\text { HTN, atrial } \\
\text { fibrillation }\end{array}$ & COPD & & Yes & $\begin{array}{l}\text { Died } 3 \text { years later from complications } \\
\text { from CVA }\end{array}$ \\
\hline G & 62 & $\mathrm{~F}$ & 1 & Never & 22.50 & & & & no & \\
\hline $\mathrm{H}$ & 75 & $\mathrm{~F}$ & 2 & Former & 26.25 & HTN & & & No & \\
\hline 1 & 85 & $\mathrm{~F}$ & 3 & Never & 17.47 & & & & No & \\
\hline
\end{tabular}

Pt: Patient; ASA: American Society of Anesthesiologists physical status classification; BMI: body mass index; F: female; M: male; HTN: hypertension; CAD: coronary artery disease; CABG: coronary artery bypass graft; IHD: ischemic heart disease; COPD: chronic obstructive pulmonary disease; CVA: cerebrovascular accident; CHF: congestive heart failure; MRSA: methicillin resistant Staphylococcus aureus.

This case series supports the use of laparoscopic TAPP repair for strangulated groin hernias. In our experience, TAPP is a safe approach with concomitant bowel resection, as long as frank perforation with gross spillage of succus does not occur. Similar recurrence rates are generally seen between the open and laparoscopic approaches, and some argue decreased complications with the laparoscopic method. TAPP gives the ability to reduce the hernia under direct visualization while permitting assessment of bowel viability in real time. Further, in the laparoscopic approach, the mesh covers the direct, indirect and femoral spaces, theoretically preventing future herniation through the other spaces, which is not always the case in open approaches.

Ultimately, the surgeon should choose the repair with which he or she is most comfortable and familiar. As surgeons become more facile with laparoscopic repair, it should be considered for incarcerated hernias due to the benefits of more complete bowel assessment for viability, reduced pain, time to recovery, and hospital stay.

\section{Conclusion}

Strangulated groin hernia is a rare medical emergency that warrants rapid operative repair. The best method of repair in this setting is not well defined, but laparoscopic repair with mesh appears to be a safe and effective option, even when bowel resection is performed. The authors support the use of laparoscopic repair if it fits the experience and comfort of the surgeon.

\section{DECLARATIONS}

\section{Authors' contributions}

Made substantial contributions to conception and design of the study and performed data analysis and interpretation: Smith A, Hope W, Fox S

Performed data acquisition, as well as provided administrative, technical, and material support: Bilezikian J, Hope W 


\section{Availability of data and materials}

Not applicable.

\section{Financial support and sponsorship}

None.

\section{Conflicts of interest}

All authors declared that there are no conflicts of interest.

\section{Ethical approval and consent to participate}

Not applicable.

\section{Consent for publication}

Not applicable.

\section{Copyright}

(c) The Author(s) 2021.

\section{REFERENCES}

1. Lal P, Kajla RK, Chander J, Saha R, Ramteke VK. Randomized controlled study of laparoscopic total extraperitoneal versus open Lichtenstein inguinal hernia repair. Surg Endosc 2003;17:850-6. DOI PubMed

2. McCormack K, Scott NW, Go PM, Ross S, Grant AM, Collaboration EUHT. Laparoscopic techniques versus open techniques for inguinal hernia repair. Cochrane Database Syst Rev 2003;1:CD001785. DOI PubMed

3. Lockhart K, Dunn D, Teo S, et al. Mesh versus non-mesh for inguinal and femoral hernia repair. Cochrane Database Syst Rev 2018;9:CD011517. DOI PubMed PMC

4. Matsuda A, Miyashita M, Matsumoto S, et al. Laparoscopic transabdominal preperitoneal repair for strangulated inguinal hernia. Asian J Endosc Surg 2018;11:155-159. DOI PubMed

5. Chihara N, Suzuki H, Sukegawa M, Nakata R, Nomura T, Yoshida H. Is the laparoscopic approach feasible for reduction and herniorrhaphy in cases of acutely incarcerated/strangulated groin and obturator hernia? J Laparoendosc Adv Surg Tech A 2019;29:6317. DOI PubMed

6. Joe C, Gowda V, Koganti S. Laparoscopic assisted repair of strangulated obturator hernia-Way to go. Int J Surg Case Rep 2019;61:246-9. DOI PubMed PMC

7. Sakamoto T, Shimaguchi M, Lefor AK, Kishida A. Laparoscopic reduction and repair of a strangulated interparietal inguinal hernia. Asian J Endosc Surg 2016;9:83-5. DOI PubMed

8. Deeba S, Purkayastha S, Paraskevas P, Athanasiou T, Darzi A, Zacharakis E. Laparoscopic approach to incarcerated and strangulated inguinal hernias. JSLS 2009;13:327-31. PubMed PMC

9. Gallegos NC, Dawson J, Jarvis M, Hobsley M. Risk of strangulation in groin hernias. Br J Surg 1991;78:1171-3. DOI PubMed

10. Drs A, Horák P, Chlupáč J, Froněk J. The most recent recommendations for the surgical treatment of inguinal hernia. Rozhl Chir 2019;98:268-72. PubMed 